\title{
Data report: a revised biomagnetostratigraphic age model for Site U1338, IODP Expedition 320/321 ${ }^{1}$
}

\author{
Jan Backman, ${ }^{2}$ Jack G. Baldauf, ${ }^{3}$ Marina Ciummelli, ${ }^{4}$ and Isabella Raffi ${ }^{5}$
}

\section{Chapter contents}

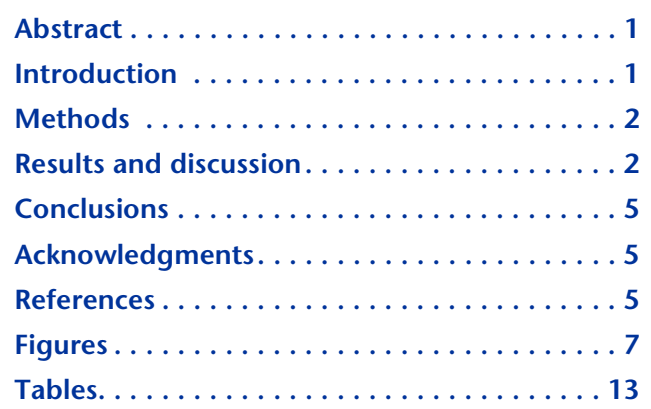

'Backman, J., Baldauf, J.G., Ciummelli, M., and Raffi, I., 2016. Data report: a revised biomagnetostratigraphic age model for Site U1338, IODP Expedition 320/321. In Pälike, H., Lyle, M., Nishi, H., Raffi, I., Gamage, K., Klaus, A., and the Expedition 320/321 Scientists, Proceedings of the Integrated Ocean Drilling Program, 320/321: Tokyo (Integrated Ocean Drilling Program Management International, Inc.).

doi:10.2204/iodp.proc.320321.219.2016 2Department of Geological Sciences, Stockholm University, SE-10691 Stockholm, Sweden. backman@geo.su.se

${ }^{3}$ Department of Oceanography, Texas A\&M University, College Station TX 77843, USA.

${ }^{4}$ Petrostrat Ltd., Tan-Y-Graig, Parc Caer Seion, LL32 8FA Conwy, United Kingdom.

${ }^{5}$ Dipartimento di Ingegneria e Geologia, Università "G. d'Annunzio" di Chieti-Pescara, I-66013 Chieti Scalo, Italy.

\begin{abstract}
The development of late middle Miocene through recent sedimentation rates was determined for Integrated Ocean Drilling Program Site U1338 in the eastern equatorial Pacific using available geomagnetic chron boundaries and biostratigraphic biohorizons provided by calcareous nannofossils and diatoms. These data were set in a revised depth splice of the three holes at Site U1338 and provide a lower resolution image of the sedimentation rate history in the region of Site U1338 through relatively long linear interpolations between 11 chosen age-depth control points encompassing $18 \mathrm{My}$. The resulting sedimentation rates depict the movement of Site U1338 from just south of the Equator with modest sedimentation rates starting at $11 \mathrm{~m} / \mathrm{My}$ to tripling of these rates near $13 \mathrm{Ma}$, when the site moved onto the Equator and into the equatorial high-productivity belt. High sedimentation rates continued into the earliest Pliocene (5 Ma) except for a $50 \%$ decrease during the so-called "carbonate crash" centered around 9.6 $\mathrm{Ma} \pm 0.4 \mathrm{My}$. The site's movement north, away from the equatorial high-productivity belt, began between 5.0 and 4.2 $\mathrm{Ma}$, when the site was located $\sim 75-90 \mathrm{nmi}$ north of the Equator, and resulted in a series of successively decreasing sedimentation rates to the present rate of $11 \mathrm{~m} / \mathrm{My}$, identical to the rate when sedimentation began at Site U1338 at nearly $18 \mathrm{Ma}$, when the site was located $\sim 100 \mathrm{nmi}$ south of the Equator.
\end{abstract}

\section{Introduction}

A key goal of Integrated Ocean Drilling Program (IODP) Expedition 320/321 (Pacific Equatorial Age Transect [PEAT]) was to recover a series of sediment sections from the Pacific paleoequator region preserving critical intervals of Cenozoic paleoceanographic and paleoclimatic conditions and development (see the "Expedition 320/321 summary" chapter [Pälike et al., 2010]). The age transect, or flow-line concept, of Pälike et al. (2010) made use of Pacific plate motion and placed sites close to the Pacific paleoequator for carefully selected time intervals that would ensure near-continuous recovery of optimally preserved early Eocene through recent sediment sections. Eight sites were drilled (Sites U1331-U1338) with present locations along an oblique northsouth transect from $12^{\circ} 4^{\prime} \mathrm{N}, 142^{\circ} 10^{\prime} \mathrm{W}$ (old end-member Site $\mathrm{U} 1331 ; 5116 \mathrm{~m}$ water depth), to $2^{\circ} 30^{\prime} \mathrm{N}, 117^{\circ} 58^{\prime} \mathrm{W}$ (young end- 
member Site U1338; 4200 m water depth). Establishing an age model for each site was a crucial component of the expedition objectives.

Sediment sections recovered from three holes at Site U1338 represent the interval from the late early Miocene at $\sim 18 \mathrm{Ma}$ to the recent. These three holes were spliced onboard using physical property data into a single continuous section with coherent depth progression from the water/sediment interface to the sediment-basalt transition, permitting determination of linear sedimentation rates from biomagnetostratigraphic data (see Fig. F14 in the "Site U1338" chapter [Expedition 320/321 Scientists, 2010b]).

IODP employs three different core depth concepts for recovered sediments. The baseline depth is in meters below seafloor (mbsf), or core depth below seafloor (CSF-A, in meters). When splicing a single continuous section from multiple holes at a single drill site, a second set of depths are assigned to the cores: composite depth below seafloor (CCSF-A, in meters). Empirically, we have learned that CCSF-A depths lie deeper than CSF-A depths and that the spliced section typically has grown in length by about $10 \%$. In the case of Site U1338, this value was $11 \%$, calculated by linear regression of CSF-A versus CCSF-A for all Site U1338 cores (see Fig. F44 in the "Site U1338" chapter [Expedition 320/321 Scientists, 2010b]). This growth factor distorts sedimentation and mass accumulation rates. To compensate for this distortion, CCSF-A depths for Site U1338 were divided by a growth factor of 1.11, resulting in a third set of depths, the corrected composite depths (CCSF-B, in meters) (see Table T23 in the "Site U1338" chapter [Expedition 320/321 Scientists, 2010b]). Subsequently, CCSF-A depth data from Site U1338 were revised by Wilkens et al. (2013), who also provide a discussion of IODP depth scale terminology.

Here, we combine revised diatom and partly revised calcareous nannofossil biostratigraphic data with shipboard magnetostratigraphic data to produce a biomagnetostratigraphic age model for Site U1338 using the Wilkens et al. (2013) revised depth data.

\section{Methods}

Shipboard calcareous nannofossil biostratigraphic and magnetostratigraphic data were acquired from all three holes at Site U1338 (see Tables T4 and T15 in the "Site U1338" chapter [Expedition 320/321 Scientists, 2010b]). Ciummelli (2013) provided additional higher resolution calcareous nannofossil biostratigraphic data for the late middle through earliest Pliocene interval that were partly published by Backman et al. (2013). Baldauf (2013) provided higher resolution diatom biostratigraphic data. See above references for methods of data acquisition. Age estimates and nomenclatures for geomagnetic chron boundaries follow the timescale of Lourens et al. (2004). Age estimates for equatorial Pacific diatom biohorizons were synthesized by Barron (1992) and are here converted from the timescale by Berggren et al. (1985) to that by Lourens et al. (2004). Age estimates for calcareous nannofossils mainly represent astronomically tuned calibrations from the western equatorial Atlantic (Backman et al., 2012).

\section{Results and discussion}

Revised CCSF-A depths for both biostratigraphic and magnetostratigraphic data were calculated by adding an offset depth to the CSF-A depth for each core, according to Table T5 in Wilkens et al. (2013). They further refined depths within cores from all three holes at Site U1338 caused by intracore stretching or squeezing and referred to these depths as "Adjusted CCSF." In Tables AT47, AT52, and AT57, Wilkens et al. (2013) adjusted depths for a total of 843 samples. Of these samples, 232 show no adjustment $(0 \mathrm{~cm})$, 281 show an average adjustment of $+16 \mathrm{~cm}$, and 330 show an average adjustment of $-17 \mathrm{~cm}$. These adjusted depths within cores are generally small but are useful for exceptionally detailed work in need of centimeter precision. Considering the uncertainties involved in the underlying data sets, we did not employ the "Adjusted CCSF" by Wilkens et al. (2013).

Growth factors for each hole are calculated by linear regression (Fig. F1) of CSF-A versus CCSF-A, following the approach from the "Site U1338" chapter (Expedition 320/321 Scientists, 2010b). The CCSF-A depth is divided by the hole-specific growth factor to obtain the corrected composite CCSF-B depth for each biomagnetostratigraphic age-depth indicator from each hole.

Site U1338 biomagnetostratigraphic age-depth data are presented in Tables T1 (calcareous nannofossils), T2 (diatoms), and T3 (magnetostratigraphy). Many individual biohorizons and magnetostratigraphic chron boundaries have been determined from two or all three Site U1338 holes (see the "Site U1338" chapter [Expedition 320/321 Scientists, 2010b]; Baldauf, 2013; Ciummelli, 2013; Backman et al., 2013). It is difficult to determine which hole provides the true or most accurate depth information for individual age-depth indicators. Hence, the midpoint of the deepest and shallowest CCSF-B depths are used for individual chron boundaries and biohorizons in the sedimentation rate plots, taking into account one, two, or all three holes from Site U1338. These midpoint CCSF-B depths show average uncertainties of $\pm 1.23 \mathrm{~m}$ (maximum $\pm 3.54 \mathrm{~m}$ ) for calcareous nanno- 
fossils, $\pm 0.86 \mathrm{~m}$ (maximum $\pm 8.23 \mathrm{~m}$ ) for diatoms, and $\pm 0.57 \mathrm{~m}$ (maximum $\pm 2.32 \mathrm{~m}$ ) for magnetostratigraphic chron boundaries.

The entire age-depth data set is presented in Figure F2. These data are composed of 33 geomagnetic chron boundaries, 33 calcareous nannofossil biohorizons, and 57 diatom biohorizons. Magnetostratigraphy is available in three different yet coherent intervals: Pliocene-Pleistocene (3.596-0.781 Ma), early late Miocene (9.987-9.098 Ma), and late middle Miocene (15.160-12.730 Ma).

Age calibrations of diatom biohorizons represent lower resolution equatorial Pacific data generated 23 years ago, which may suggest potential room for improvement (as always in biochronology). Still, the diatom biohorizons generally align well with magnetostratigraphic chron boundaries and calcareous nannofossil biohorizons, presumably because $75 \%$ of the diatom biohorizons (Table T2) have been directly calibrated with geomagnetic polarity stratigraphies from the equatorial Pacific (Barron, 1992) in depositional settings similar to that of Site U1338. In the 9.0 through $12.9 \mathrm{Ma}$ interval, however, only 23\% (3 of 13) of the diatom biohorizons are directly calibrated with magnetostratigraphy.

In order to show details of the different parts of the sedimentation rate history at Site U1338, the record is divided into three parts: 0-5.2 Ma (Fig. F3), 5-10.2 Ma (Fig. F4), and 9.9-18 Ma (Fig. F5). The proposed rate-determining age-depth indicators, or control points (CPs), and the resulting linear sedimentation rates (LSRs) are presented in Table T4.

It appears clearly from Figure F2 that the 123 agedepth indicators fall into coherent linear intervals, albeit with some minor scatter. Minor variations in sedimentation rates presumably occurred in the presented linear intervals between the nearest chosen age-depth CP couplets. It is beyond the scope of this data report to accommodate for such minor variations, which would require highly resolved cyclostratigraphic or stable isotopic data correlated to sites with independent (magnetostratigraphic) age control to resolve properly. When allowing for minor scatter in these biomagnetostratigraphic data, the suggested LSRs become uniform over relatively long intervals. This is considered preferable in comparison to, for example, placing CPs at each progressively deeper age-depth indicator, which would still result in scatter but also cause artificial extremes in sedimentation rates between closely spaced agedepth indicator couplets.

Age estimates of late early Miocene through Pleistocene geomagnetic chron boundaries are considered well constrained (Lourens et al., 2004), yet we have permitted a few such boundaries in the older/deeper part of the record to fall slightly off the proposed interpolated rate lines (Fig. F5) so as to not introduce extreme, shorter variations in sedimentation rates caused by less well constrained depths or age estimates of a few chron boundaries.

With these caveats, this data report may be taken to provide a basic biomagnetostratigraphic reference framework for future attempts to develop highly resolved age models for Site U1338 based on, for example, carbon isotope stratigraphy or astronomically tuned cyclostratigraphy.

We are fully aware of that the relatively few (11) interpolated linear sedimentation rate intervals encompassing the past $18 \mathrm{My}$ at Site U1338 may be drawn differently, yet we consider that the proposed sedimentation rate history represents a reasonable interpretation of the age-depth distribution of available magnetostratigraphic, diatom, and calcareous nannofossil data. All depths below are on the CCSFB scale.

\section{Sedimentation rate lines between 0 and $5 \mathrm{Ma}$}

Pliocene-Pleistocene sedimentation rates are shown in Figure F3. The youngest rate line is determined by the top of the Site U1338 sediment sequence, placed at $0.00 \mathrm{~m}$ and $0.00 \mathrm{Ma}$, and the Chron $\mathrm{C} 1 \mathrm{n} / \mathrm{C} 1 \mathrm{r}$ boundary (base Brunhes; CP1).

CP2 is the Chron C2n/C2r.1r boundary (base Olduvai), and CP3 is the Chron C2An.3n/C2Ar boundary (base Gauss). There are two diatom and three calcareous nannofossil biohorizons clearly falling to the left of the proposed rate line between $\mathrm{CP} 2$ and $\mathrm{CP} 3$, suggesting that these represent paleoecologically driven disappearances prior to their genuine extinctions.

The three nannofossil extinctions represent Discoaster species, two of which have known problematic abundance histories toward the end of their ranges in the equatorial Pacific (Backman and Shackleton, 1983). It remains uncertain why the diatom biohorizons at $4.7 \mathrm{Ma}$ (top Fragilariopsis cylindrica) and 4.9 Ma (base Nitzschia jouseae) deviate from the proposed interpolated line controlled by CP4 (base Asteromphalus elegans at $4.2 \mathrm{Ma}$ ) and CP5 (top Ceratolithus acutus at $5.04 \mathrm{Ma}$ ).

\section{Sedimentation rate lines between 5 and $10 \mathrm{Ma}$}

A constant sedimentation rate is suggested over $4 \mathrm{My}$ from CP5 in the earliest Pliocene to CP6 (base Chron CAn) in the early late Miocene (Fig. F4). Two nannofossil biohorizons are clearly off the line, one being 
the top of the absence interval (paracme) of Reticulofenestra pseudoumbilicus (7.09 Ma) and the other the base of Amaurolithus spp. (7.39 Ma). Both biohorizons appear unproblematic in terms of abundance patterns (Backman et al., 2013). The former biohorizon does not represent the evolutionary first appearance of the species but rather its reappearance after having been virtually absent from the assemblages for about 1.7 My for reasons unknown. Its position suggests a reduced absence interval of about $0.4 \mathrm{My}$ at its upper end in the region of Site U1338, as the proposed interpolated line suggests a reappearance at 7.5 Ma rather than 7.1 Ma. Base Amaurolithus spp. seems to appear at $\sim 0.3 \mathrm{My}$ earlier $(7.7 \mathrm{Ma}$ rather than $7.4 \mathrm{Ma}$ ) to the Site U1338 region compared with its calibrated first appearance from both the western equatorial Atlantic and two sites in the eastern equatorial Pacific (Backman et al., 2012). In Monte dei Corvi section on the Adriatic Sea coast, base Amaurolithus spp. occurs in the middle part of Chron C4n.1n at an estimated age of 7.57 Ma (Di Stefano et al., 2010), which would bring this biohorizon to within $0.1 \mathrm{My}$ from the proposed interpolated line. These data suggest that this biohorizon is diachronous, perhaps up to $0.3 \mathrm{My}$, as suggested at Site U1338.

The interval between CP6 and CP7 is controlled by geomagnetic chron boundaries, one of which only marginally fits the proposed rate line. Top Catinaster coalitus at 9.70 Ma disappeared from the Site U1338 region well prior to its calibrated extinction. Not surprisingly, the final part of its range is characterized by low and discontinuous abundances (Backman et al., 2013).

\section{Sedimentation rate lines between 10 and $18 \mathrm{Ma}$}

The interval between geomagnetic chron boundaries CP7 and CP8 encompasses 3.2 My (Fig. F5). Even if this interval is divided using one or two intermediate biostratigraphic CPs, biohorizons will still be scattered around the shorter interpolation alternative.

Between CP8 and CP9, four geomagnetic chron boundaries do not fit the proposed linear interpolation. Less good core conditions began to affect the splice and composite section toward the deep end of the sequence (see "Site U1338" in the "Expedition 320/321 summary" chapter [Pälike et al., 2010]), which presumably affected the positions of some of the deepest geomagnetic chron boundaries. For example, in Holes U1338B and U1338C (Table T3), the series of successively older geomagnetic chron boundaries shows a corresponding successive increase in depth. When combining the data from the two holes to calculate midpoint depths of individual chron boundaries from their lowermost and uppermost occurrences, the obvious progression of depth in the individual holes dissolves, suggesting that the two holes are not perfectly correlated in their deepest parts. The position of, for example, the C5ADr/ C5Bn.1n boundary in Hole U1338B at 14.781 Ma occurs above $(354.00 \mathrm{~m})$ the younger $(14.581 \mathrm{Ma})$ C5ADn/C5ADr boundary at $356.44 \mathrm{~m}$ in Hole U1338C (Table T3). We therefore used only data from Hole U1338C for the four deepest geomagnetic chron boundaries in order to maintain a logical depth progression of each successive chron boundary.

The lowermost part of the Site U1338 sedimentation rate history is based on nannofossil biostratigraphy. The short overlap between two nannofossil biohorizons at $15.69 \mathrm{Ma}$ (Discoaster deflandrei decreases to $<30 \%$ of the total Discoaster assemblage) and 15.73 Ma (base Discoaster signus) indicates that CP10 can be confidently placed at the latter biohorizon. The base of common Sphenolithus heteromorphus provides CP11, which has a consistent first common occurrence in Chron C5Dr in the Indian Ocean, Atlantic Ocean, and Mediterranean Sea (Backman et al., 1990, 2012; Di Stefano et al., 2015).

\section{Sedimentation rates versus age}

The sedimentation rate history at Site U1338 shows distinct variability and some general trends (Fig. F6; Table T4). When plotting the sedimentation rate history using linear interpolation between specific agedepth indicators, rates change stepwise at the CPs. We assume that the rate history was more smooth than depicted in Figure F6 and that the changes did not generally occur at the CPs but more likely as transitions between the CPs.

Rates were modest ( $11 \mathrm{~m} / \mathrm{My})$ during the first $2 \mathrm{My}$ of sedimentation at Site U1338, when the site was located $\sim 100 \mathrm{nmi}$ south of the Equator (see Fig. F5 in the "Expedition 320/321 summary" chapter [Pälike et al., 2010]). Sedimentation rates thereafter increased to $34 \mathrm{~m} / \mathrm{My}$ by $\sim 13.2 \mathrm{Ma}$, when the site began to approach the Equator from the south. This high rate was maintained for about 3 My until the rate was halved to $17 \mathrm{~m} / \mathrm{My}$ between 10.0 and 9.1 Ma.

This major yet temporary decrease in sedimentation rate coincides with intense carbonate dissolution at Site U1338, also known as the "carbonate crash," in the eastern equatorial Pacific (Farrell et al., 1995; Lyle et al., 1995). The most intense dissolution occurs over a $0.72 \mathrm{~m}$ thick interval within Section 321U1338B-22H-2, with a minimum carbonate content of $5 \%$ and an average of $12 \%$ between 198.85 and 199.57 m (Lyle and Backman, 2013) corresponding 
to a $42 \mathrm{ky}$ long interval according to the present age model, beginning at $9.618 \mathrm{Ma}$ and ending at 9.576 Ma.

Carbonate content and the sedimentation rate increased after this early late Miocene carbonate crash at $\sim 9.6 \mathrm{Ma}$ to $30 \mathrm{~m} / \mathrm{My}$ for a $4.1 \mathrm{My}$ long interval lasting into the earliest Pliocene. This late Miocene rate regime changed in the early Pliocene between 5.0 and 4.2 Ma into a new Pliocene-Pleistocene sedimentation rate regime with an average of $14 \mathrm{~m} / \mathrm{My}$ representing a decrease of $56 \%$ compared with the late Miocene regime. Exactly when this major decrease occurs is unclear. If extrapolating the late Miocene regime upward and the early Pliocene regime downward, these will meet at $\sim 4.8 \mathrm{Ma}$, when the site was located $\sim 80 \mathrm{nmi}$ north of the Equator (see Fig. F5 in the "Expedition 320/321 summary" chapter [Pälike et al., 2010]).

Pliocene-Pleistocene sedimentation rates are, however, not uniform, but they show a stepwise decrease from $18 \mathrm{~m} / \mathrm{My}(5.0-4.2 \mathrm{Ma})$ to $15 \mathrm{~m} / \mathrm{My}(4.2-3.6$ $\mathrm{Ma})$, followed by $13 \mathrm{~m} / \mathrm{My}(3.6-1.9 \mathrm{Ma})$ to $12 \mathrm{~m} / \mathrm{My}$ $(1.9-0.8 \mathrm{Ma})$ and finally $11 \mathrm{~m} / \mathrm{My}(0.8-0.0 \mathrm{Ma})$, as Site U1338 is slowly moving away from the Equatorial high productivity region.

\section{Conclusions}

Late middle Miocene through recent linear sedimentation rates were calculated for IODP Site U1338 in the eastern equatorial Pacific using available geomagnetic chron boundary data together with calcareous nannofossil and diatom biochronologic data. Rather than attempting to use every age-depth indicator for estimates of sedimentation rates, we selected 11 key control points to describe a low-resolution sedimentation history, thus permitting for scatter around the proposed interpolated rate lines.

The sedimentation rate history at Site U1338 mirrors the movement of the site from $\sim 2^{\circ} 45^{\prime} \mathrm{S}$ of the Pacific Equator to its present location at $2^{\circ} 30^{\prime} \mathrm{N}$ of the Equator, crossing a high-productivity zone during the late middle Miocene through earliest Pliocene times and resulting in sedimentation rates on the order of $30-34 \mathrm{~m} / \mathrm{My}$. Sedimentation rates started at a modest rate $(11 \mathrm{~m} / \mathrm{My})$ when the Site U1338 basalt crust was formed, ramped up in three steps to a tripling at $\sim 13.2 \mathrm{Ma}$ to $34 \mathrm{~m} / \mathrm{My}$, and decreased by $50 \%$ during the so-called carbonate crash between 10.0 and $9.1 \mathrm{Ma}$. The crash was followed by an increase to $30 \mathrm{~m} / \mathrm{My}$ that lasted for $\sim 4 \mathrm{My}$ into the earliest Pliocene (5.0 Ma). Thereafter, sedimentation rates decreased successively in five steps to its present rate of $11 \mathrm{~m} / \mathrm{My}$.

\section{Acknowledgments}

This research used data and samples provided by the Integrated Ocean Drilling Program (IODP). J. Backman acknowledges financial support from the Swedish Research Council and Stockholm University. Reviews by Samantha Gibbs and Anna Joy Drury helped improve the manuscript.

\section{References}

Backman, J., Raffi, I., Ciummelli, M., and Baldauf, J., 2013. Species-specific responses of late Miocene Discoaster spp. to enhanced biosilica productivity conditions in the equatorial Pacific and the Mediterranean. GeoMarine Letters, 33(4):285-298. http://dx.doi.org/10.1007/s00367-013-0328-0

Backman, J., Raffi, I., Rio, D., Fornaciari, E., and Pälike, H., 2012. Biozonation and biochronology of Miocene through Pleistocene calcareous nannofossils from low and middle latitudes. Newsletters on Stratigraphy, 45(3):221-244. http://dx.doi.org/10.1127/0078-0421/2012/0022

Backman, J., Schneider, D.A., Rio, D., and Okada, H., 1990. Neogene low-latitude magnetostratigraphy from Site 710 and revised age estimates of Miocene nannofossil datum events. In Duncan, R.A., Backman, J., Peterson, L.C., et al., Proceedings of the Ocean Drilling Program, Scientific Results, 115: College Station, TX (Ocean Drilling Program), 271-276.

http://dx.doi.org/10.2973/odp.proc.sr.115.209.1990

Backman, J., and Shackleton, N.J., 1983. Quantitative biochronology of Pliocene and early Pleistocene calcareous nannofossils from the Atlantic, Indian and Pacific Oceans. Marine Micropaleontology, 8(2):141-170. http://dx.doi.org/10.1016/0377-8398(83)90009-9

Baldauf, J.G., 2013. Data report: diatoms from Sites U1334 and U1338, Expedition 320/321. In Pälike, H., Lyle, M., Nishi, H., Raffi, I., Gamage, K., Klaus, A., and the Expedition 320/321 Scientists, Proceedings of the Integrated Ocean Drilling Program, 320/321: Tokyo (Integrated Ocean Drilling Program Management International, Inc.). http://dx.doi.org/10.2204/ iodp.proc.320321.215.2013

Barron, J.A., 1992. Neogene diatom datum levels in the equatorial and North Pacific. In Ishizaki, K., and Saito, T. (Eds.), Centenary of Japanese Micropaleontology: Tokyo (Terra Scientific Publishing Company), 413-425. http:// www.terrapub.co.jp/e-library/cjm/pdf/0413.pdf

Berggren, W.A., Kent, D.V., and Van Couvering, J.A., 1985. The Neogene, Part 2. Neogene geochronology and chronostratigraphy. In Snelling, N.J. (Ed.), The Chronology of the Geological Record. Memoir-Geological Society of London, 10:211-260. http://dx.doi.org/10.1144/GSL.MEM.1985.010.01.18

Ciummelli, M., 2013. Morphometry, evolution, biostratigraphy and paleoecology of the genus Discoaster in the Miocene using material from Site U1338, IODP Exp. 321 [Ph.D. dissertation]. University of Chieti-Pescara, Italy. 
Di Stefano, A., Baldassini, N., Maniscalco, R., Speranza, F., Maffione, M., Cascella, A., and Foresi, L.M., 2015. New bio-magnetostratigraphic data on the Miocene Moria section (Northern Apennines, Italy): connections between the Mediterranean region and the North Atlantic Ocean. Newsletters on Stratigraphy, 48(2):135-152. http://dx.doi.org/10.1127/nos/2015/0057

Di Stefano, A., Verducci, M., Lirer, F., Ferraro, L., Iaccarino, S.M., Hüsing, S.K., and Hilgen, F.J., 2010. Paleoenvironmental conditions preceding the Messinian Salinity Crisis in the central Mediterranean: integrated data from the upper Miocene Trave section (Italy). Palaeogeography, Palaeoclimatology, Palaeoecology, 297(1):37-53. http://dx.doi.org/10.1016/j.palaeo.2010.07.012

Expedition 320/321 Scientists, 2010a. Methods. In Pälike, H., Lyle, M., Nishi, H., Raffi, I., Gamage, K., Klaus, A., and the Expedition 320/321 Scientists, Proceedings of the Integrated Ocean Drilling Program, 320/321: Tokyo (Integrated Ocean Drilling Program Management International, Inc.). http://dx.doi.org/10.2204/ iodp.proc.320321.102.2010

Expedition 320/321 Scientists, 2010b. Site U1338. In Pälike, H., Lyle, M., Nishi, H., Raffi, I., Gamage, K., Klaus, A., and the Expedition 320/321 Scientists, Proceedings of the Integrated Ocean Drilling Program, 320/321: Tokyo (Integrated Ocean Drilling Program Management International, Inc.). http://dx.doi.org/10.2204/ iodp.proc.320321.110.2010

Farrell, J.W., Raffi, I., Janecek, T.R., Murray, D.W., Levitan, M., Dadey, K.A., Emeis, K.-C., Lyle, M., Flores, J.-A., and Hovan, S., 1995. Late Neogene sedimentation patterns in the eastern equatorial Pacific Ocean. In Pisias, N.G., Mayer, L.A., Janecek, T.R., Palmer-Julson, A., and van Andel, T.H. (Eds.), Proceedings of the Ocean Drilling Program, Scientific Results, 138: College Station, TX (Ocean Drilling Program), 717-756.

http://dx.doi.org/10.2973/odp.proc.sr.138.143.1995

Lourens, L.J., Hilgen, F.J., Shackleton, N.J., Laskar, J., and Wilson, D., 2004. The Neogene period. In Gradstein, F.M., Ogg, J.G., and Smith, A.G. (Eds.), A Geological Time Scale 2004. Cambridge, UK (Cambridge Univ. Press), 409-440.

Lyle, M., and Backman, J., 2013. Data report: calibration of XRF-estimated $\mathrm{CaCO}_{3}$ along the Site U1338 splice. In
Pälike, H., Lyle, M., Nishi, H., Raffi, I., Gamage, K., Klaus, A., and the Expedition 320/321 Scientists, Proceedings of the Integrated Ocean Drilling Program, 320/321: Tokyo (Integrated Ocean Drilling Program Management International, Inc.). http://dx.doi.org/10.2204/ iodp.proc.320321.205.2013

Lyle, M., Dadey, K.A., and Farrell, J.W., 1995. The late Miocene (11-8 Ma) eastern Pacific carbonate crash: evidence for reorganization of deep-water circulation by the closure of the Panama gateway. In Pisias, N.G., Mayer, L.A., Janecek, T.R., Palmer-Julson, A., and van Andel, T.H. (Eds.), Proceedings of the Ocean Drilling Program, Scientific Results, 138: College Station, TX (Ocean Drilling Program), 821-838. http://dx.doi.org/10.2973/odp.proc.sr.138.157.1995

Pälike, H., Nishi, H., Lyle, M., Raffi, I., Gamage, K., Klaus, A., and the Expedition 320/321 Scientists, 2010. Expedition 320/321 summary. In Pälike, H., Lyle, M., Nishi, H., Raffi, I., Gamage, K., Klaus, A., and the Expedition 320/ 321 Scientists, Proceedings of the Integrated Ocean Drilling Program, 320/321: Tokyo (Integrated Ocean Drilling Program Management International, Inc.). http:// dx.doi.org/10.2204/iodp.proc.320321.101.2010

Raffi, I., Backman, J., Fornaciari, E., Pälike, H., Rio, D., Lourens, L., and Hilgen, F., 2006. A review of calcareous nannofossil astrobiochronology encompassing the past 25 million years. Quaternary Science Reviews, 25(2324):3113-3137. http://dx.doi.org/10.1016/j.quascirev.2006.07.007

Wilkens, R.H., Dickens, G.R., Tian, J., Backman, J., and the Expedition 320/321 Scientists, 2013. Data report: revised composite depth scales for Sites U1336, U1337, and U1338. In Pälike, H., Lyle, M., Nishi, H., Raffi, I., Gamage, K., Klaus, A., and the Expedition 320/321 Scientists, Proceedings of the Integrated Ocean Drilling Program, 320/321: Tokyo (Integrated Ocean Drilling Program Management International, Inc.). http:// dx.doi.org/10.2204/iodp.proc.320321.209.2013

Initial receipt: 8 September 2015

Acceptance: 5 November 2015

Publication: 11 February 2016

MS 320321-219 
Figure F1. CSF-A versus CCSF-A depths for tops of cores, Site U1338. Growth factors = slope of the regression line for each hole.

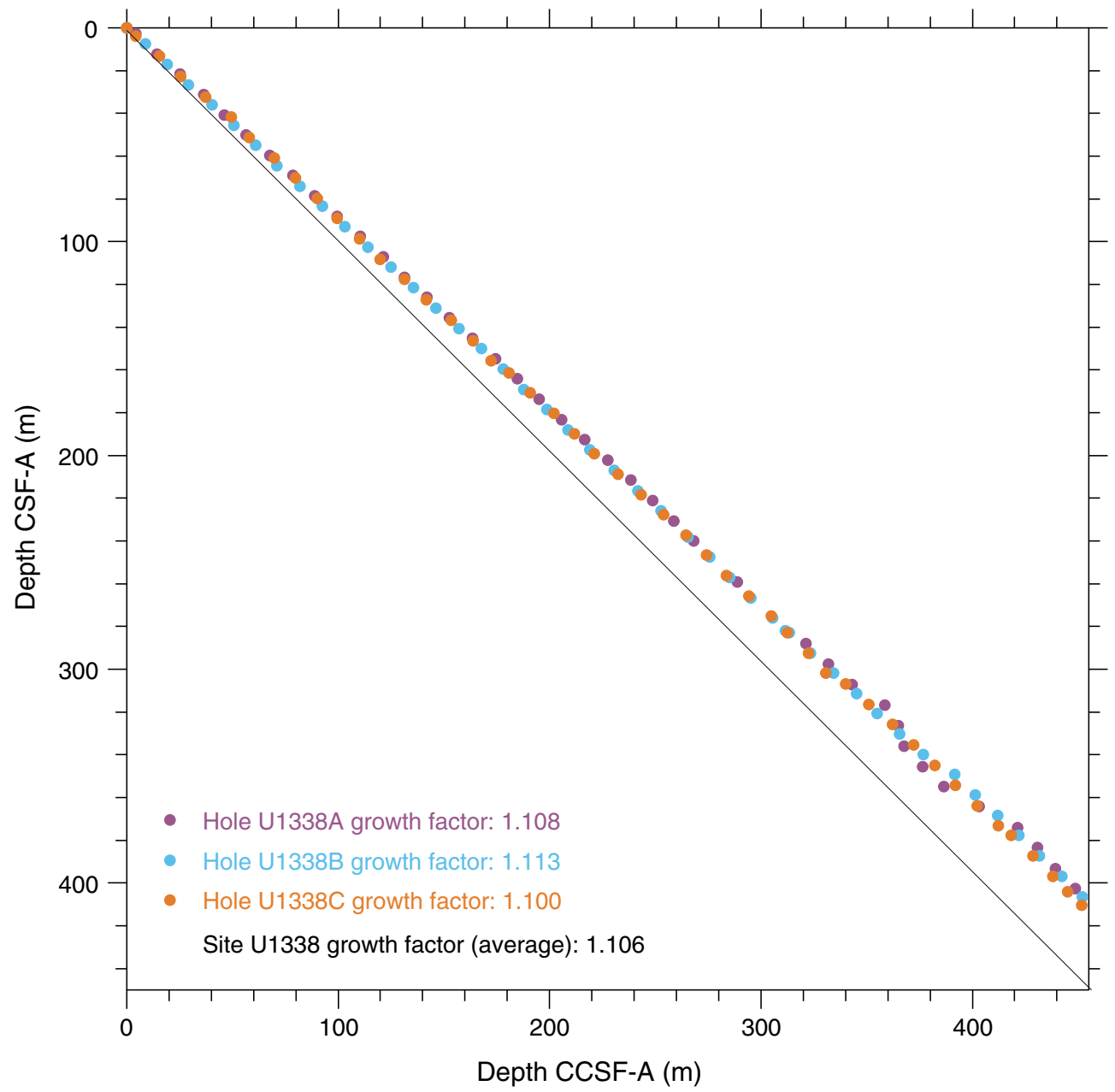


Figure F2. Biomagnetostratigraphic indicators, 0-18 Ma, Site U1338. Symbols are shown with error bars in the depth domain, representing the lowermost and uppermost depths of biohorizons and chron boundaries (Tables T1, T2, T3).

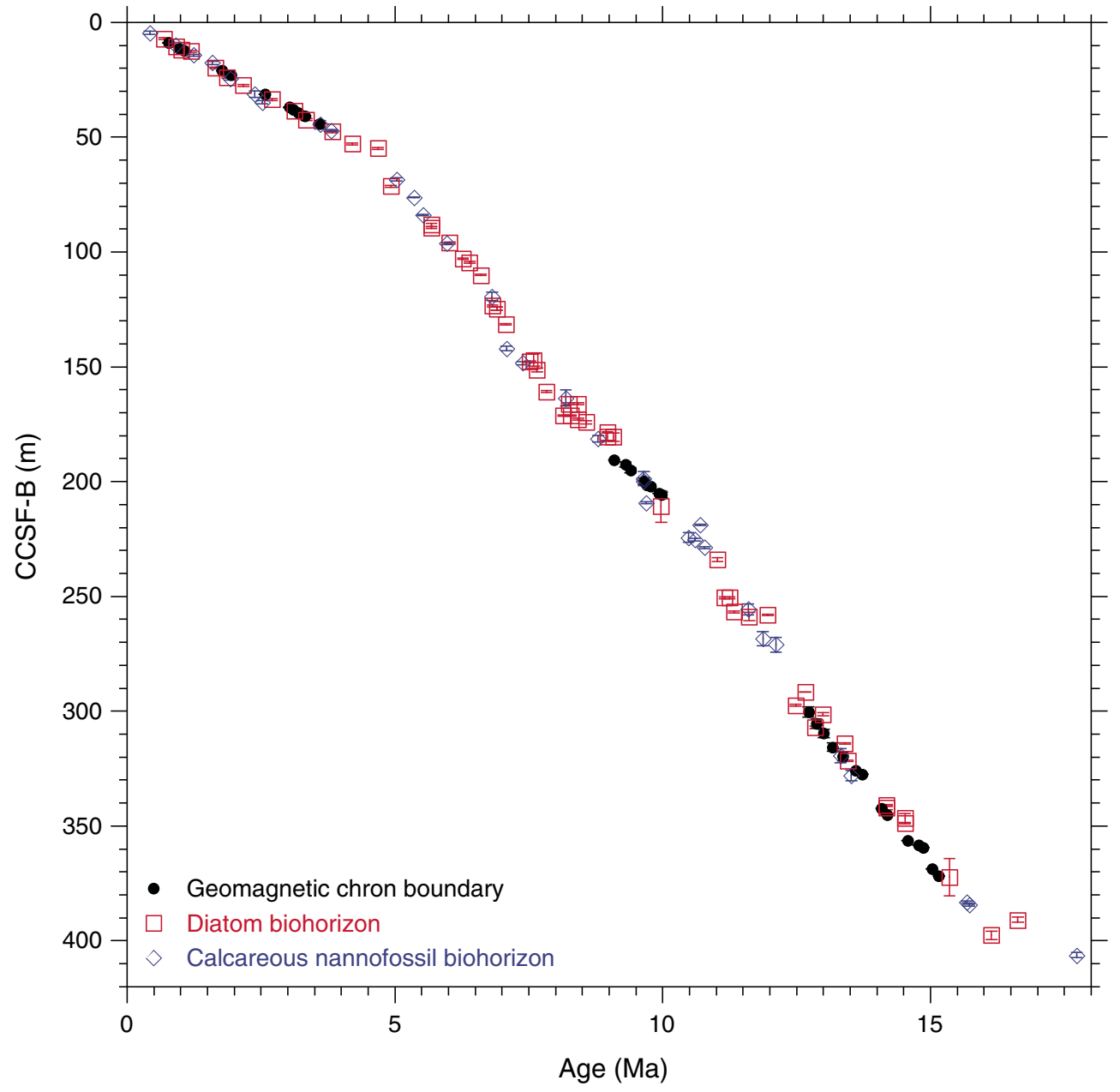


Figure F3. Biomagnetostratigraphic indicators, 0-5.2 Ma, Site U1338. See Table T4 for CPs and LSRs. Symbols are shown with error bars in the depth domain, representing the lowermost and uppermost depths of biohorizons and chron boundaries (Tables T1, T2, T3).

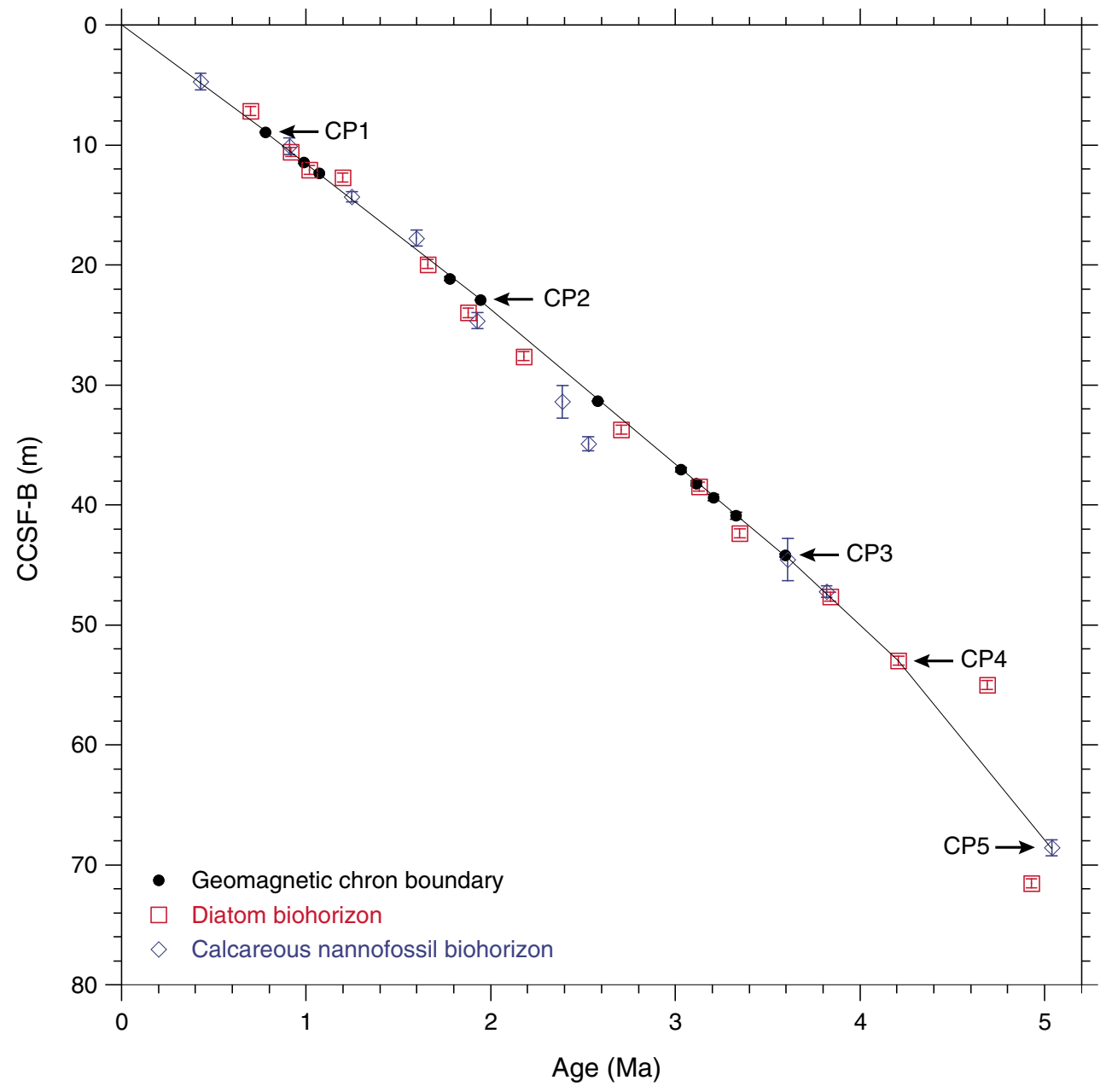


Figure F4. Biomagnetostratigraphic indicators, 5.0-10.2 Ma, Site U1338. See Table T4 for CPs and LSRs. Symbols are shown with error bars in the depth domain, representing the lowermost and uppermost depths of biohorizons and chron boundaries (Tables T1, T2, T3).

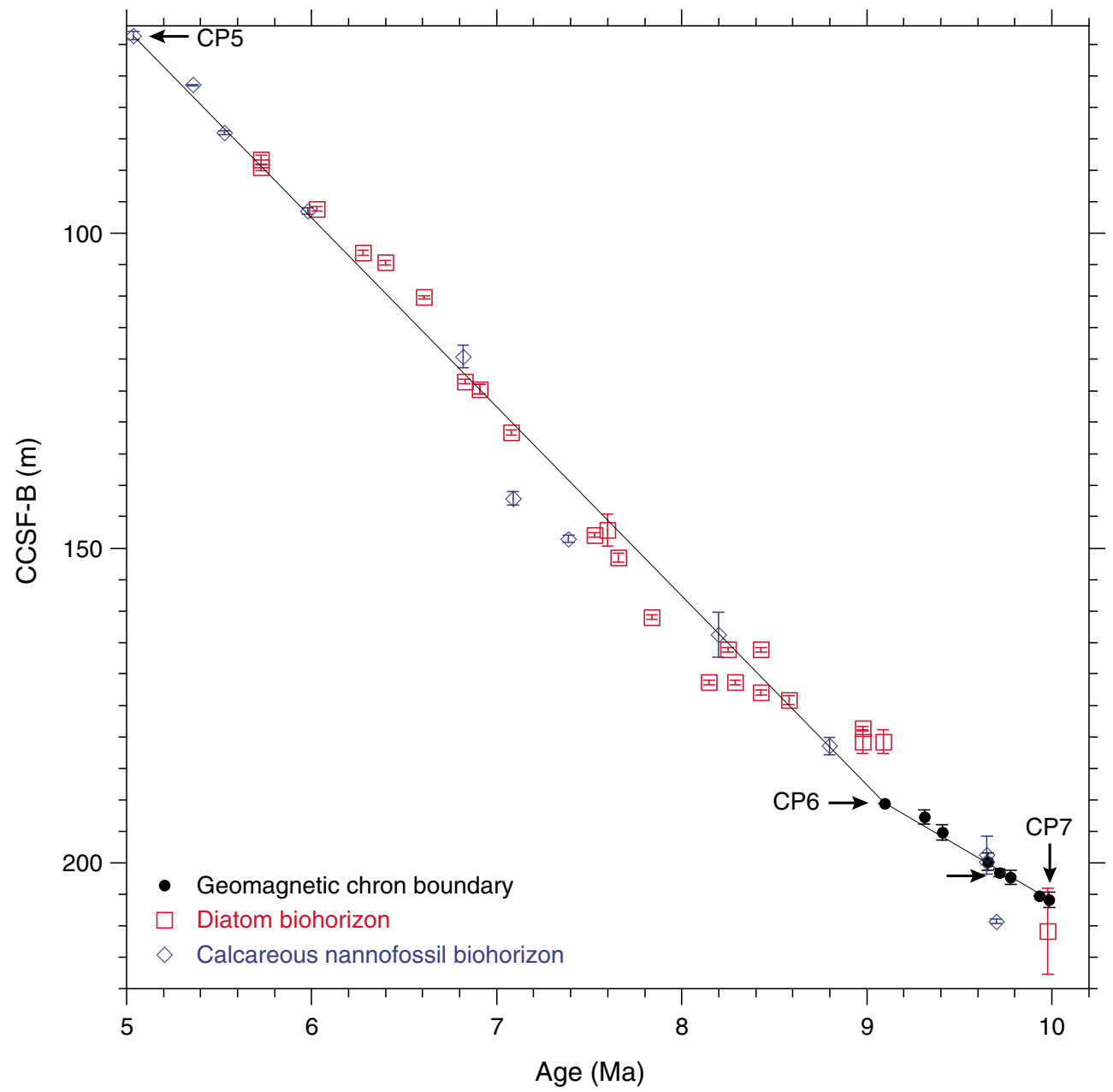


Figure F5. Biomagnetostratigraphic indicators, 10-18 Ma, Site U1338. See Table T4 for CPs and LSRs. Site U1338 terminal depth $=413.6 \mathrm{~m}$ CCSF-B at $18.4 \mathrm{Ma}$. Symbols are shown with error bars in the depth domain, representing the lowermost and uppermost depths of biohorizons and chron boundaries (Tables T1, T2, T3).

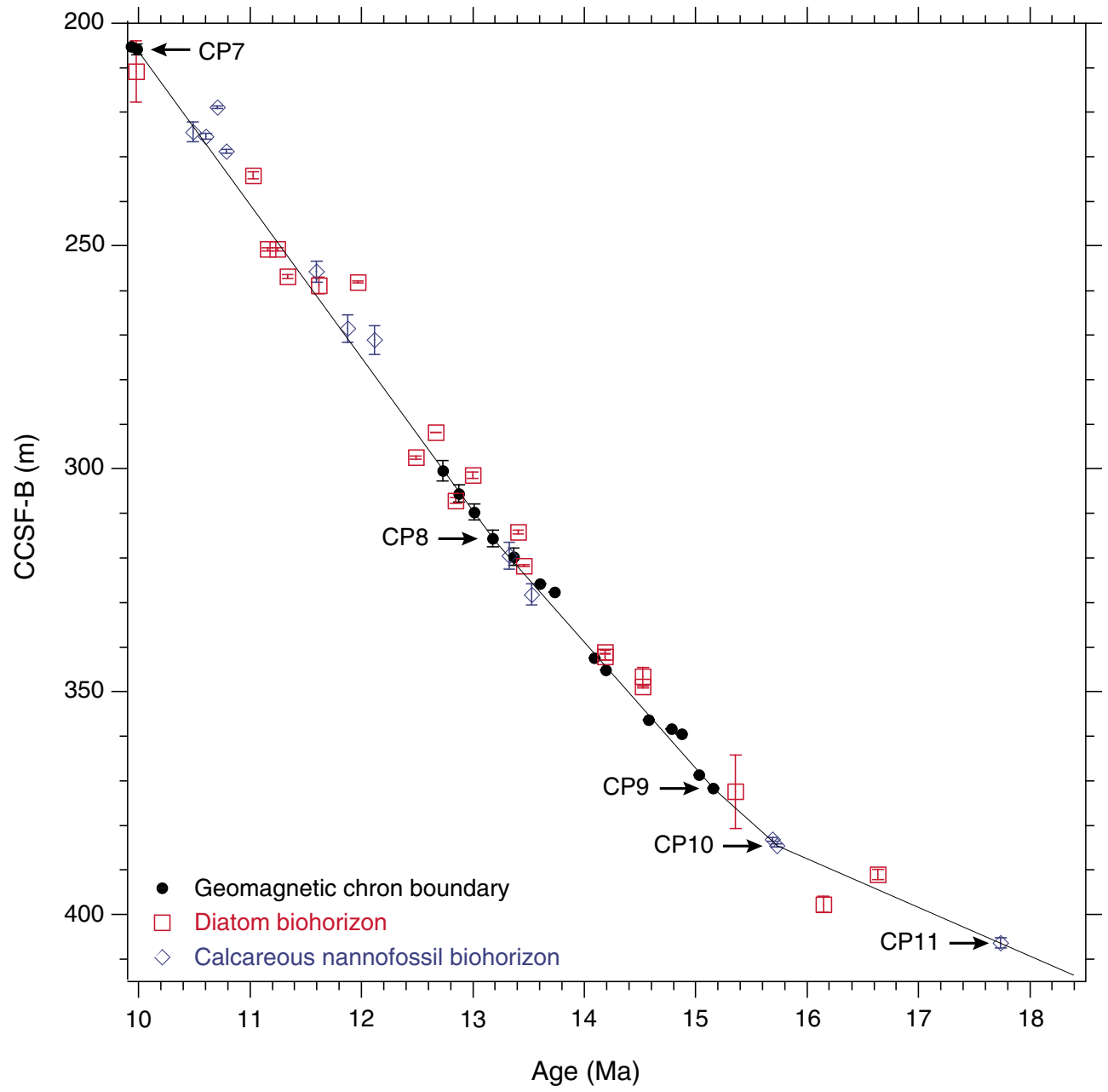


Figure F6. Linear sedimentation rate versus age. CP numbers in plot refer to Table T4. Estimated paleolatitude positions of Site U1338 are from Figure F5 in the "Expedition 320/321 summary" chapter (Pälike et al., 2010).

Site U1338 located in high productivity zone

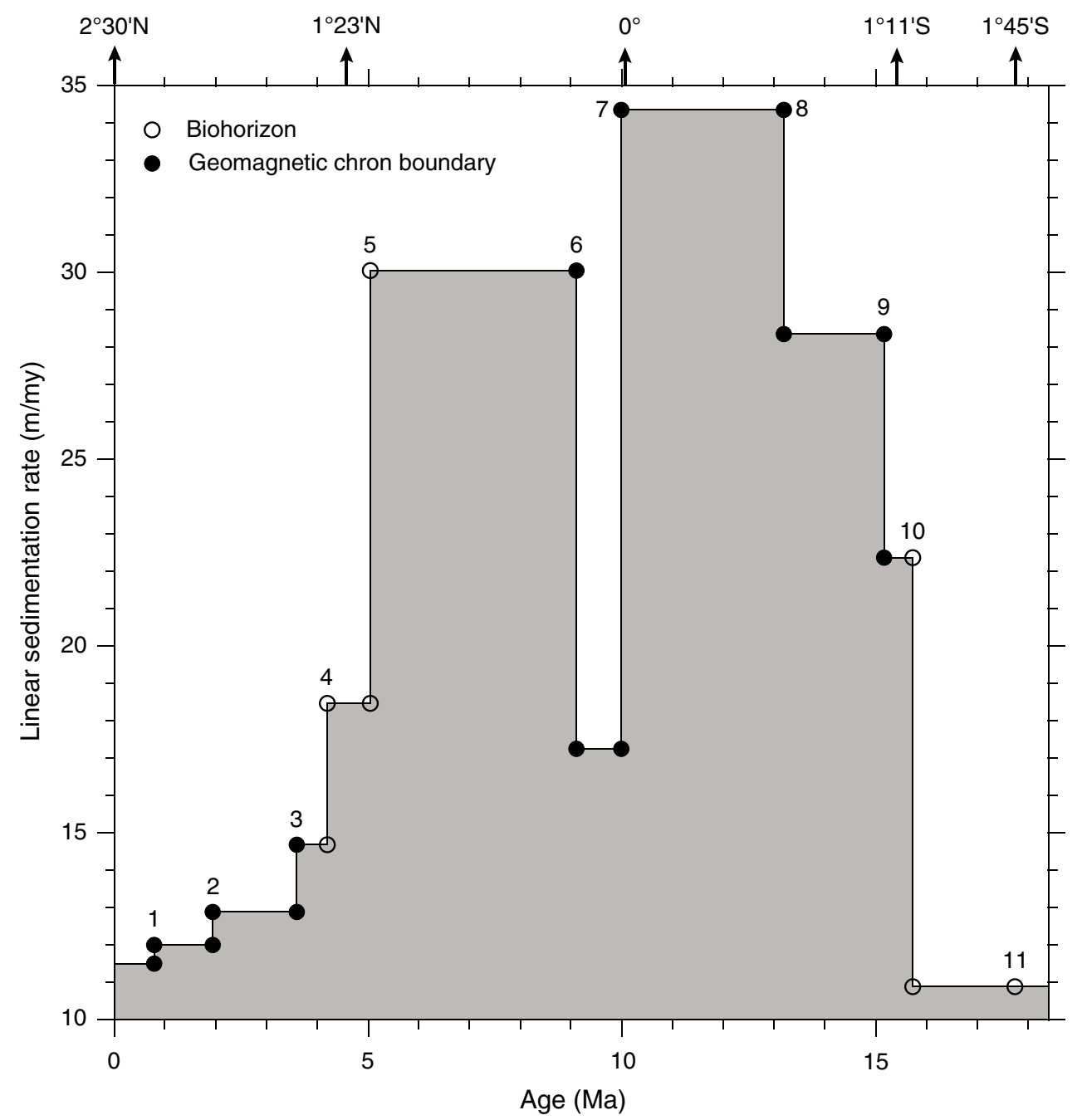


Table T1. Biomagnetostratigraphic age-depth data for calcareous nannofossils, Site U1338. This table is available in oversized format. 
Table T2. Biomagnetostratigraphic age-depth data for diatoms, Site U1338.

\begin{tabular}{|c|c|c|c|c|c|c|c|c|c|c|}
\hline Diatom biohorizon & $\begin{array}{l}\text { Age } \\
\text { (Ma) }\end{array}$ & $\begin{array}{l}\text { Top } \\
\text { hole, core, section, } \\
\text { interval (cm) }\end{array}$ & $\begin{array}{l}\text { Bottom } \\
\text { hole, core, section, } \\
\text { interval (cm) }\end{array}$ & $\begin{array}{l}\text { Top depth } \\
\text { CSF-A }(m)\end{array}$ & $\begin{array}{c}\text { Bottom depth } \\
\text { CSF-A (m) }\end{array}$ & $\begin{array}{l}\text { Top depth } \\
\text { CCSF-A (m) }\end{array}$ & $\begin{array}{l}\text { Bottom depth } \\
\text { CCSF-A (m) }\end{array}$ & $\begin{array}{l}\text { Revised depth } \\
\text { (indpoint) } \\
\text { CCSF-B (m) }\end{array}$ & $\begin{array}{l}\text { Uncertainty } \\
( \pm \mathrm{m})\end{array}$ & $\begin{array}{l}\text { Calibrated with } \\
\text { magneto- } \\
\text { stratigraphy }\end{array}$ \\
\hline & & & & & & & & & & \\
\hline $\begin{array}{l}\text { T Fragingariopsis reinhondditi } \\
\text { T Fragilariopsis fossilis }\end{array}$ & $\begin{array}{l}0.70 \\
0.92\end{array}$ & $\begin{array}{l}U 1338 \mathrm{~A}-2 \mathrm{H}-3,35 \\
41328 \mathrm{~A}-5\end{array}$ & $\begin{array}{l}U 1338 \mathrm{~A}-2 \mathrm{H}-3,120 \\
\text { U1338A-20 }\end{array}$ & 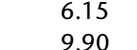 & $\begin{array}{r}6.90 \\
10.65\end{array}$ & $\begin{array}{c}7.63 \\
11.38\end{array}$ & $\begin{array}{r}8.38 \\
12.13\end{array}$ & 7.022 & $\begin{array}{l}0.38 \\
0.38\end{array}$ & $\begin{array}{l}\text { Yes } \\
\text { No }\end{array}$ \\
\hline T Rhizosolenia matuyamai & 1.02 & U1338B-2H-3, 120 & $\mathrm{U} 1338 \mathrm{~B}-2 \mathrm{H}-4,45$ & 11.80 & 12.55 & 13.09 & 13.84 & 12.10 & & \\
\hline B Rhizosolenia matuyamai & 1.2 & U1 $1338 \mathrm{~B}-2 \mathrm{H}-4,45$ & U1338B-2H-4, 120 & 12.55 & 13.30 & 13.84 & 14.59 & 12.77 & 0.38 & Yes \\
\hline T Rhizosolenia praebergonii var, robusta & 1.66 & $\mathrm{U} 1338 \mathrm{~B}-3 \mathrm{H}-2,120$ & U1338B-3H-3, 45 & 19.80 & 20.55 & 21.87 & 22.62 & 19.99 & 0.38 & Yes \\
\hline B Fragilariopsis doliolus & 1.9 & U1338B-3H-5, 120 & U1338B-3H-6, 45 & 24.30 & 25.05 & 26.37 & 27.12 & 24.03 & 0.38 & Yes \\
\hline $\begin{array}{l}\text { TThalassiosira convexa var. convexa } \\
\text { T Nitzchig juoseae }\end{array}$ & 2.2 & $\begin{array}{l}\text { U1338A-4H-4, } 45 \\
\text { U1338A-5H-1 45 }\end{array}$ & $\begin{array}{l}\text { U1338A-4H-4, } 120 \\
\text { U13338-5H-1,120 }\end{array}$ & $\begin{array}{l}26.65 \\
31.65\end{array}$ & 27.40 & 30.27 & $\begin{array}{l}31.02 \\
2780\end{array}$ & $\begin{array}{l}27.66 \\
22.78\end{array}$ & 0.38 & Yes \\
\hline T N Nitzschia jouseae & 2.7 & 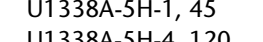 & U1338A-5H-1, 120 & 31.65 & 32.40 & 37.05 & 37.80 & 33.78 & 0.38 & Yes \\
\hline 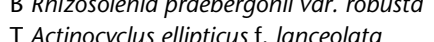 & $\begin{array}{l}3.1 \\
3.4\end{array}$ & $\begin{array}{l}01338 A-H-S-4,520 \\
01338-5 H-5,45\end{array}$ & U1338B-5H-5, 120 & $\begin{array}{l}36.90 \\
4255\end{array}-10$ & $\begin{array}{l}37.65 \\
43.30\end{array}$ & $\begin{array}{l}42.30 \\
4685\end{array}$ & $\begin{array}{l}43.05 \\
4760\end{array}$ & 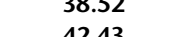 & $\begin{array}{l}0.38 \\
0.38\end{array}$ & Yes \\
\hline B Thalassiosira convexa var. convexa & $\begin{array}{l}. .4 \\
3.8\end{array}$ & $\mathrm{U} 1338 \mathrm{~B}-6 \mathrm{H}-2,45$ & U1338B-6H-2, 120 & 47.55 & 48.30 & 52.69 & $\begin{array}{l}43.44 \\
53.44\end{array}$ & 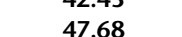 & 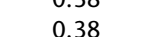 & 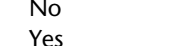 \\
\hline B Asteromphalus elegans & & U1338A-7H-2, 45 & U1338A-7H-2, 120 & 52.15 & 52.90 & 58.36 & & 53.01 & & $\begin{array}{l}\text { Yes } \\
\text { Yes }\end{array}$ \\
\hline T Fragalariopsis cylindrica & 4.7 & U1338A-7H-3, 120 & U1338A-7H-4, 45 & 54.40 & 55.15 & 60.61 & 61.36 & 55.04 & 0.38 & $\begin{array}{l}\text { res } \\
\text { Yes }\end{array}$ \\
\hline B Nitzschia jouseae & 4.9 & & U1 $338 \mathrm{~A}-9 \mathrm{H}-1,120$ & 72.55 & (n) & & 79.85 & 71.58 & & \\
\hline B Shionodiscus oestrupii & 5.7 & U1338B-10H-4, 45 & U1338B-10H-5, 45 & 88.55 & 90.05 & & 99.05 & 88.32 & 0.75 & Yes \\
\hline T Thalassiosira miocenica & 5.7 & U1338B-10H-5, 45 & U1 $338 A-11 \mathrm{H}-1,45$ & 90.05 & 88.65 & 99.05 & 99.93 & 89.59 & 0.44 & Yes \\
\hline T Asterolampra acutiloba & 6.03 & $\mathrm{U} 1338 \mathrm{~B}-11 \mathrm{H}-3,45$ & U1338B-11H-3, 120 & 96.55 & 97.30 & 106.67 & 107.42 & 96.18 & 0.38 & Yes \\
\hline T Fragilariopsis miocenica & 6.28 & 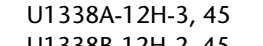 & U1338A-12H-3, 120 & 101.15 & 101.90 & 113.90 & 114.65 & 103.14 & 0.38 & Yes \\
\hline I Nitzschia miocenica var. elongata & 6.40 & $\begin{array}{ll}U 13388-12 H-2,45 \\
0\end{array}$ & $U 1338 B-12 H-2,120$ & 104.55 & 105.30 & 116.14 & 116.89 & 104.69 & 0.38 & Yes \\
\hline 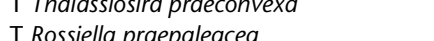 & $\begin{array}{l}6.6 \\
68\end{array}$ & 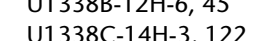 & $\begin{array}{l}U 1338 \mathrm{~A}-13 \mathrm{H}-1,1,120 \\
\text { U1 } 1388 \mathrm{C}-14 \mathrm{H}-4,4\end{array}$ & $\begin{array}{l}110.55 \\
122.02\end{array}$ & $\begin{array}{l}108.40 \\
12777-250\end{array}$ & $\begin{array}{l}12.14 \\
13560\end{array}$ & 122.67 & $\begin{array}{l}110.23 \\
13261\end{array}$ & 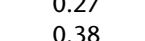 & $\begin{array}{l}\text { Yes } \\
\text { Yes }\end{array}$ \\
\hline 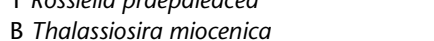 & 6.0 & 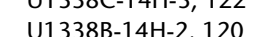 & 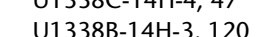 & 124,30 & 1258 & & & 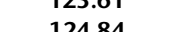 & & Yes \\
\hline B Thalassiosira convexa & 6.9 & U1338B-14H-2, 120 & U1338B-14H-3, 120 & 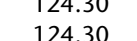 & 12580 & $\begin{array}{l}138.20 \\
13820\end{array}$ & $\begin{array}{l}139.10 \\
130\end{array}$ & 121.484 & 0.075 & $\begin{array}{r}\text { Yes } \\
\text { Yos }\end{array}$ \\
\hline B Thalassiosira praeconvexa & 7.1 & U $1338 \mathrm{~A}-15 \mathrm{HH}-3,45$ & U1338A-15H-3, 120 & 129.65 & 130.40 & 1450 & 14625 & 131.66 & 0 & $Y_{e}$ \\
\hline T Nitzschia porteri & 7.5 & $\mathrm{U} 1338 \mathrm{~B}-16 \mathrm{H}-\mathrm{S}, 120$ & 6,45 & 30 & 148.55 & 16 & 08 & 88 & & Yes \\
\hline ocenica & 7.60 & $\mathrm{U} 1338 \mathrm{~A}-16 \mathrm{H}-6,45$ & U1 $1338 \mathrm{~A}-17 \mathrm{H}-2,45$ & 143.65 & 147.15 & 160.56 & 165.68 & 147.22 & 56 & Yes \\
\hline T Rossiella paleacea & 7.7 & $\mathrm{U} 1338 \mathrm{~A}-17 \mathrm{H}-3,45$ & U1338A-17H-4, 45 & 148.65 & 150.15 & 167.18 & 168.68 & 151.56 & 0.75 & Yes \\
\hline T Thalassiosira burckliana & 7.8 & U1338A-18H-3, 45 & U1338A-18H-3, 120 & 158.15 & 158.90 & 178.03 & 178.78 & 161.02 & 0.38 & Yes \\
\hline sis reinholdiii & 8.2 & $\begin{array}{ll}U 13388-19 H-2,120 \\
0\end{array}$ & $1-3,45$ & & & 190.40 & & & 0.38 & Yes \\
\hline $\begin{array}{l}\text { A Actinocyclus ellipticus var. javanica } \\
\text { B Avveus marinus }\end{array}$ & $\begin{array}{l}8.25 \\
8.3\end{array}$ & $\begin{array}{l}\text { U113388-18H-5, } 45 \\
\text { U13338-194-2,20 }\end{array}$ & $\begin{array}{l}\text { U1338BB-18H-5, } 120 \\
\text { U1338B-19H-3, }\end{array}$ & $\begin{array}{l}166.05 \\
171.80\end{array}$ & $\begin{array}{l}166.80 \\
17255\end{array}$ & $\begin{array}{l}184.61 \\
19040\end{array}$ & $\begin{array}{l}185.36 \\
19115\end{array}$ & $\begin{array}{l}166.20 \\
174141\end{array}$ & $\begin{array}{l}0.38 \\
0.38\end{array}$ & $\begin{array}{l}\text { Yes } \\
\text { Yes }\end{array}$ \\
\hline $\begin{array}{l}\text { B Alveus marimus } \\
\text { T Thalassiosira yabe }\end{array}$ & $\begin{array}{l}8.3 \\
8.43\end{array}-3$ & $\begin{array}{l}0 \\
\mathrm{U} \\
\mathrm{U}\end{array}$ & U1338B-18H-5, 120 & $\begin{array}{l}171.80 \\
166.05\end{array}$ & $\begin{array}{l}1 / 2.25 \\
166.80\end{array}$ & $\begin{array}{l}190.040 \\
184.61\end{array}$ & $\begin{array}{l}19.13 \\
185.36\end{array}$ & $\begin{array}{l}17.464 \\
166.20\end{array}$ & $\begin{array}{l}0.38 \\
0.38\end{array}$ & $\begin{array}{l}\text { Yes } \\
\text { Yes }\end{array}$ \\
\hline B Fragilariopsis cylindrica & $\begin{array}{l}0.45 \\
8.43\end{array}$ & U1338A-19H-5, 45 & U1338A-19H-5, 120 & 170.65 & $\begin{array}{l}171.40 \\
171.40\end{array}$ & $\begin{array}{l}104.01 \\
191.30\end{array}$ & 192.05 & $\begin{array}{l}10.020 \\
172.99\end{array}$ & 0.38 & $\begin{array}{l}\text { res } \\
\text { Yes }\end{array}$ \\
\hline B Azpeitia nodulifera var. cyclopa & 8.6 & U1 $1338 \mathrm{~A}-19 \mathrm{H}-6,45$ & U1338B-19H-5, 45 & 172.15 & 175.55 & 192.80 & 194.15 & 174.22 & 0.67 & Yes \\
\hline B Fragilariopsis fossilis & 9.0 & $\mathrm{U} 1338 \mathrm{~A}-2 \mathrm{OH}-3,45$ & U1338A-20H-5, 120 & 177.15 & 180.90 & 198.44 & 202.19 & 180.79 & 1.88 & No \\
\hline B Thalassiosira yabei var. elliptica & 9.0 & U1338A-20H-2, 120 & U1338A-20H-3, 45 & 176.40 & 177.15 & & 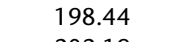 & 178.76 & 0.38 & No \\
\hline B Thalassiosira burckliana & 9.1 & $\begin{array}{l}U 1338 \mathrm{~A}-20 \mathrm{H}-3,45 \\
403280\end{array}$ & U1338 & $\begin{array}{l}177.15 \\
20580-200\end{array}$ & $\begin{array}{l}180.90 \\
21728\end{array}$ & 198.44 & 19 & 180.79 & 1.88 & $\begin{array}{r}\text { Yes } \\
\text { Yos }\end{array}$ \\
\hline $\begin{array}{l}\text { TActinoccyclus moronensis } \\
\text { T Cavitatus jouseana }\end{array}$ & $\begin{array}{l}10.0 \\
11.0\end{array}$ & $\begin{array}{l}U 133388-222-6-670 \\
\mathrm{U} 3338 \mathrm{~B}-25 \mathrm{H}-\mathrm{5}, 45\end{array}$ & $\begin{array}{l}13138 \mathrm{AA}-24 \mathrm{~A}-\mathrm{-}, 2,108 \\
\text { U1338A }\end{array}$ & $\begin{array}{l}205.80 \\
232.55\end{array}$ & $\begin{array}{l}214.28 \\
232.65\end{array}$ & $\begin{array}{l}227.42 \\
259.26\end{array}$ & 246.93 & $\begin{array}{l}213.95 \\
23.21\end{array}$ & $\begin{array}{l}6.85 \\
0.83\end{array}$ & $\begin{array}{l}\text { Yes } \\
\text { No }\end{array}$ \\
\hline iscus coscinodiscus & 11.2 & 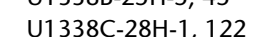 & 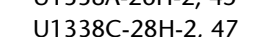 & 248.02 & 248.87 & 275.68 & & 250.78 & 0.38 & No \\
\hline var. diorama & 11.3 & $\mathrm{U} 1338 \mathrm{C}-28 \mathrm{H}-1,122$ & U1338C-28H-2, 47 & 248.02 & 248.77 & 275.48 & 276.23 & 250.78 & 0.38 & No \\
\hline T Actinocyclus ellipticus var. spiralis & 11.3 & $\mathrm{U} 1338$ & U1338 & 254.77 & 255.52 & 282.23 & 282.98 & 256.91 & 0.38 & No \\
\hline cuneiformis & 11.6 & 013 & 013 & 258.30 & 262.05 & 286.35 & 290.10 & 258.96 & 1.88 & Yes \\
\hline $\begin{array}{l}\text { T Actinocyclus ing } \\
\text { T Crucideticula n }\end{array}$ & 12.0 & 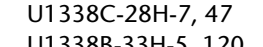 & 1645 & 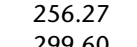 & & & 23150 & $\begin{array}{l}258.16 \\
2507 \\
2075\end{array}$ & 25 & No \\
\hline $\begin{array}{l}\text { TC Crucidenticicala nicobarica } \\
\text { T Annellus califoricus }\end{array}$ & $\begin{array}{l}12.5 \\
12.7\end{array}$ & $\begin{array}{l}U 133388-333-5-5,120 \\
\text { U1 } 338 C-334-1,47\end{array}$ & 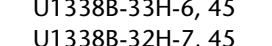 & $\begin{array}{l}299.60 \\
292.87\end{array}$ & $\begin{array}{l}300.35 \\
293235\end{array}$ & $\begin{array}{l}330.75 \\
3291\end{array}$ & $\begin{array}{l}331.50 \\
3297\end{array}$ & 29186 & $\begin{array}{l}0.38 \\
0.03\end{array}$ & $\begin{array}{l}\text { No } \\
\text { No }\end{array}$ \\
\hline B Coscinodiscus gigas var. diorama & 12.9 & U1 338B-334-14-4,45 & U1338C-35H-1, 47 & $\begin{array}{l}292.8 / \\
306.85\end{array}$ & $\begin{array}{l}29.235 \\
307.37\end{array}$ & $\begin{array}{l}32.291 \\
339.28\end{array}$ & 340.50 & $\begin{array}{l}291.186 \\
307.18\end{array}$ & 0.61 & $\begin{array}{l}\text { No } \\
\text { No }\end{array}$ \\
\hline visianus & 13.0 & U1 $1338 \mathrm{~B}-34 \mathrm{H}-1,45$ & $\mathrm{U} 133$ & 302.35 & 303.85 & 334.78 & 336.28 & 301.46 & 0.75 & Yes \\
\hline tappanae & 13.41 & $\mathrm{U} 1338 \mathrm{~B}-35 \mathrm{H}-3,120$ & U133 & & & & 350.13 & 314.25 & 38 & Yes \\
\hline B Azpe & 13.5 & U1338C-36H- & $\mathrm{U} 133$ & 321.37 & 322.10 & 35 & 356.24 & 321.82 & 15 & Yes \\
\hline TC & 14.2 & & & & & & & & 88 & Yes \\
\hline 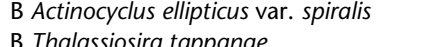 & 14.2 & 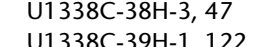 & $\begin{array}{ll}U 1338 \mathrm{C}-38 \mathrm{H}-\mathrm{Y} \\
\mathrm{U}\end{array}$ & $\begin{array}{l}338.87 \\
346.12\end{array}$ & $\begin{array}{l}340.37 \\
3485\end{array}$ & $\begin{array}{l}375.66 \\
38342\end{array}-12$ & $\begin{array}{l}377.16 \\
38415\end{array}$ & $\begin{array}{l}342.19 \\
3490\end{array}$ & 0.75 & $\begin{array}{l}\text { No } \\
\text { Yes }\end{array}$ \\
\hline $\begin{array}{l}\text { atcopanae } \\
\text { blysmos }\end{array}$ & 14.5 & $01338 \mathrm{C}$ & v133 & $\begin{array}{l}340.12 \\
342.62\end{array}$ & 346 & $\begin{array}{l}30.42 \\
379.41\end{array}$ & 383.42 & $\begin{array}{l}346.74 \\
346.74\end{array}$ & 2.00 & $\begin{array}{l}\text { Yes } \\
\text { No }\end{array}$ \\
\hline 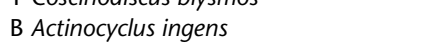 & 15.4 & 22 & 22 & 363 & 379 & & & & & No \\
\hline & 16.6 & & $44 \mathrm{H}-2,220$ & 387.85 & 390.1 & 429.0 & 431: 3 & 391.08 & & \\
\hline B Cestodiscus peplum & 16.2 & U1338C-44H-5, 120 & U1338C-45H-1, 120 & 394.60 & 398.10 & 435.81 & 439.31 & 397.78 & 1.75 & Yes \\
\hline
\end{tabular}

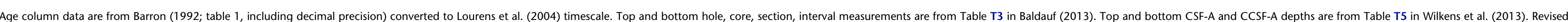
Age column data are from Barron (1992; table 1, including decimal precision) converted to Lourens et al. (2004) timescale. Top and bottom hole, core, section, interal
depth = midpoint CCSF-A (m)/site growth factor (Fig. F1). Calibration data are from Barron (1992). Bold = shallowest and deepest depths of individual biohorizons. 
Table T3. Biomagnetostratigraphic age-depth data based on magnetostratigraphy, Site U1338.

\begin{tabular}{|c|c|c|c|c|c|c|c|c|c|c|c|c|c|c|c|c|c|}
\hline $\begin{array}{l}\text { Geomagnetic polarity } \\
\text { chron boundary }\end{array}$ & $\begin{array}{l}\text { Age } \\
\text { (Ma) }\end{array}$ & $\begin{array}{l}\text { Core, section, } \\
\text { interval }(\mathrm{cm})\end{array}$ & $\begin{array}{c}\text { Depth } \\
\text { CSF-A (m) }\end{array}$ & $\begin{array}{c}\text { Depth } \\
\text { CCSF-A (m) }\end{array}$ & $\begin{array}{l}\text { Revised depth } \\
\text { CCSF-B }(\mathrm{m})\end{array}$ & $\begin{array}{l}\text { Core, section, } \\
\text { interval }(\mathrm{cm})\end{array}$ & $\begin{array}{l}\text { Depth } \\
\text { CSF-A (m) }\end{array}$ & $\begin{array}{c}\text { Depth } \\
\text { CCSF-A (m) }\end{array}$ & $\begin{array}{l}\text { Revised depth } \\
\text { CCSF-B (m) }\end{array}$ & $\begin{array}{l}\text { Core, section, } \\
\text { interval }(\mathrm{cm})\end{array}$ & $\begin{array}{c}\text { Depth } \\
\text { CSF-A (m) }\end{array}$ & $\begin{array}{c}\text { Depth } \\
\text { CCSF-A (m) }\end{array}$ & $\begin{array}{l}\text { Revised depth } \\
\text { CCSF-B }(\mathrm{m})\end{array}$ & $\begin{array}{l}\text { Top depth } \\
\text { Site U1338 } \\
\text { CCSF-B (m) }\end{array}$ & $\begin{array}{l}\text { Bottom depth } \\
\text { Site U1338 } \\
\text { CCSF-B (m) }\end{array}$ & $\begin{array}{c}\text { Depth } \\
\text { (midpoint) } \\
\text { CCSF-B }(\mathrm{m})\end{array}$ & $\begin{array}{c}\text { Depth } \\
\text { uncertainty } \\
( \pm \mathrm{m})\end{array}$ \\
\hline & & 321-U1338A- & & & & 321-U1338B- & & & & 321-U1338C- & & & & & & & \\
\hline $\mathrm{C} 1 \mathrm{n} / \mathrm{C} 1 \mathrm{r} .1 \mathrm{r}$ & 0.781 & $2 \mathrm{H}-4,122$ & 8.42 & 9.90 & 8.94 & $2 \mathrm{H}-1,115$ & 8.75 & 10.04 & 9.02 & $2 \mathrm{H}-4,105$ & 9.38 & 9.93 & 9.03 & 8.94 & 9.03 & 8.98 & 0.05 \\
\hline C1r.1r/C1r.1n & 0.988 & $2 \mathrm{H}-6,92$ & 11.12 & 12.60 & 11.37 & $2 \mathrm{H}-3,85$ & 11.45 & 12.74 & 11.45 & $2 \mathrm{H}-6,87$ & 12.17 & 12.72 & 11.56 & 11.37 & 11.56 & 11.47 & 0.10 \\
\hline $\mathrm{C} 1 \mathrm{r} .1 \mathrm{n} / \mathrm{C} 1 \mathrm{r} .2 \mathrm{r}$ & 1.072 & $2 \mathrm{H}-7,42$ & 12.12 & 13.60 & 12.27 & $2 \mathrm{H}-4,27$ & 12.37 & 13.66 & 12.27 & $2 \mathrm{H}-7,40$ & 13.20 & 13.75 & 12.50 & 12.27 & 12.50 & 12.39 & 0.11 \\
\hline $\mathrm{C} 1 \mathrm{r} .3 \mathrm{r} / \mathrm{C} 2 \mathrm{n}$ & 1.778 & $3 \mathrm{H}-7,0$ & 21.20 & 23.43 & 21.15 & $3 \mathrm{H}-3,120$ & 21.30 & 23.37 & 21.00 & $3 \mathrm{H}-6,40$ & 21.20 & 23.51 & 21.37 & 21.00 & 21.37 & 21.19 & 0.19 \\
\hline $\mathrm{C} 2 \mathrm{n} / \mathrm{C} 2 \mathrm{r} \cdot 1 \mathrm{r}$ & 1.945 & & & & & $3 \mathrm{H}-5,37$ & 23.47 & 25.54 & 22.95 & $3 \mathrm{H}-7,67$ & 22.97 & 25.28 & 22.98 & 22.95 & 22.98 & 22.96 & 0.02 \\
\hline C2r.2r/C2An.1n & 2.581 & $4 \mathrm{H}-7,48$ & 31.18 & 34.80 & 31.41 & $4 \mathrm{H}-4,112$ & 32.22 & 34.88 & 31.34 & & & & & 31.34 & 31.41 & 31.37 & 0.03 \\
\hline C2An. $1 \mathrm{n} / \mathrm{C} 2 \mathrm{An} .1 \mathrm{r}$ & 3.032 & $5 \mathrm{H}-3,130$ & 35.50 & 40.90 & 36.91 & $5 \mathrm{H}-1,75$ & 36.85 & 41.15 & 36.97 & $5 \mathrm{H}-3,47$ & 35.77 & 41.03 & 37.30 & 36.91 & 37.30 & 37.11 & 0.19 \\
\hline C2An.1r/C2An.2n & 3.116 & $5 \mathrm{H}-5,0$ & 37.20 & 42.60 & 38.45 & $5 \mathrm{H}-2,4$ & 38.00 & 42.30 & 38.01 & $5 \mathrm{H}-4,17$ & 36.97 & 42.23 & 38.39 & 38.01 & 38.45 & 38.23 & 0.22 \\
\hline C2An.2n/C2An.2r & 3.207 & & & & & $5 \mathrm{H}-3,18$ & 39.28 & 43.58 & 39.16 & $5 \mathrm{H}-5,10$ & 38.40 & 43.66 & 39.69 & 39.16 & 39.69 & 39.42 & 0.27 \\
\hline C2An.2r/C2An.3 & 3.330 & $5 \mathrm{H}-6,140$ & 40.10 & 45.50 & 41.06 & $5 \mathrm{H}-4,32$ & 40.92 & 45.22 & 40.63 & $5 \mathrm{H}-6,30$ & 40.10 & 45.36 & 41.24 & 40.63 & 41.24 & 40.93 & 0.30 \\
\hline C2An.3n/C2Ar & 3.596 & $6 \mathrm{H}-2,140$ & 43.60 & 49.16 & 44.37 & $5 \mathrm{H}-6,120$ & 44.80 & 49.10 & 44.12 & & & & & 44.12 & 44.37 & 44.24 & 0.13 \\
\hline C4An/C4Ar.1r & 9.098 & & & & & & & & & $21 \mathrm{H}-6,15$ & 187.95 & 209.66 & 190.60 & 190.60 & 190.60 & 190.60 & 0.00 \\
\hline C4Ar.1r/C4Ar.1n & 9.312 & $21 \mathrm{H}-6,10$ & 190.80 & 213.29 & 192.50 & $21 \mathrm{H}-4,0$ & 192.60 & 213.35 & 191.69 & $22 \mathrm{H}-1,140$ & 191.20 & 213.33 & 193.94 & 191.69 & 193.94 & 192.81 & 1.12 \\
\hline C4Ar. $1 n / C 4 A r .2 r$ & 9.409 & $22 \mathrm{H}-1,10$ & 192.80 & 216.70 & 195.58 & $21 \mathrm{H}-5,110$ & 195.20 & 215.95 & 194.03 & $22 \mathrm{H}-3,112$ & 193.92 & 216.05 & 196.41 & 194.03 & 196.41 & 195.22 & 1.19 \\
\hline C4Ar.2r/C4Ar.2n & 9.656 & $22 \mathrm{H}-3,122$ & 196.92 & 220.82 & 199.30 & $22 \mathrm{H}-2,22$ & 199.32 & 220.94 & 198.51 & $22 \mathrm{H}-7,50$ & 199.30 & 221.43 & 201.30 & 198.51 & 201.30 & 199.90 & 1.40 \\
\hline C4Ar.2n/C4Ar.3r & 9.717 & $22 \mathrm{H}-5,10$ & 198.80 & 222.70 & 200.99 & $22 \mathrm{H}-3,60$ & 201.20 & 222.82 & 200.20 & $23 \mathrm{H}-1,125$ & 200.55 & 222.53 & 202.30 & 200.99 & 202.30 & 201.65 & 0.65 \\
\hline C4Ar.3r/C5n.1n & 9.779 & $2 \angle \pi-3,10$ & 190.00 & $2 \angle 2.10$ & 200.79 & $22 \mathrm{H}-4,22$ & 202.32 & 223.94 & 201.20 & $23 \mathrm{H}-2,105$ & 201.85 & 223.83 & 203.48 & 201.20 & 203.48 & 202.34 & $\begin{array}{l}.03 \\
1.14\end{array}$ \\
\hline C5n.1n/ C5n.1r & 9.934 & $23 \mathrm{H}-1,15$ & 202.35 & 227.54 & 205.36 & & & & & & & & & 205.36 & 205.36 & 205.36 & 0.00 \\
\hline C5n.1r/C5n.2n & 9.987 & & & & & $22 \mathrm{H}-6,117$ & 206.27 & 227.89 & 204.75 & $23 \mathrm{H}-5,57$ & 205.87 & 227.85 & 207.14 & 204.75 & 207.14 & 205.94 & 1.19 \\
\hline C5Ar.1r/C5Ar.1n & 12.730 & & & & & $33 \mathrm{H}-6,87$ & 300.77 & 331.92 & 298.22 & $34 \mathrm{H}-2,95$ & 304.35 & 333.14 & 302.85 & 298.22 & 302.85 & 300.54 & 2.32 \\
\hline C5Ar.2n/C5Ar.3r & 12.878 & & & & & $34 \mathrm{H}-3,67$ & 305.57 & 338.00 & 303.68 & $34 \mathrm{H}-6,17$ & 309.57 & 338.36 & 307.60 & 303.68 & 307.60 & 305.64 & 1.96 \\
\hline C5Ar.3r/C5AAn & 13.015 & & & & & $34 \mathrm{H}-6,90$ & 310.30 & 342.73 & 307.93 & $35 \mathrm{H}-2,125$ & 309.65 & 342.78 & 311.62 & 307.93 & 311.62 & 309.78 & 1.84 \\
\hline C5AAn/C5AAr & 13.183 & & & & & $35 \mathrm{H}-3,117$ & 315.57 & 349.35 & 313.88 & $35 \mathrm{H}-7,35$ & 316.25 & 349.38 & 317.62 & 313.88 & 317.62 & 315.75 & 1.87 \\
\hline C5AAr/C5ABn & 13.369 & & & & & $35 \mathrm{H}-6,110$ & 320.00 & 353.78 & 317.86 & $36 \mathrm{H}-2,140$ & 319.30 & 353.87 & 321.70 & 317.86 & 321.70 & 319.78 & 1.92 \\
\hline $\mathrm{C} 5 \mathrm{ABn} / \mathrm{C} 5 \mathrm{ABr}$ & 13.605 & & & & & $36 \mathrm{H}-6,15$ & 328.59 & 362.73 & 325.90 & & & & & 325.90 & 325.90 & 325.90 & 0.00 \\
\hline $\mathrm{C} 5 \mathrm{ABr} / \mathrm{C} 5 \mathrm{ACn}$ & 13.734 & & & & & $36 \mathrm{H}-7,65$ & 330.55 & 364.69 & 327.66 & & & & & 327.66 & 327.66 & 327.66 & 0.00 \\
\hline $\mathrm{C} 5 \mathrm{ACn} / \mathrm{C} 5 \mathrm{ACr}$ & 14.095 & & & & & & & & & $38 \mathrm{H}-4,0$ & 339.90 & 376.69 & 342.45 & 342.45 & 342.45 & 342.45 & 0.00 \\
\hline $\mathrm{C} 5 \mathrm{ACr} / \mathrm{C} 5 \mathrm{ADn}$ & 14.194 & & & & & & & & & $38 \mathrm{H}-6,0$ & 342.90 & 379.69 & 345.17 & 345.17 & 345.17 & 345.17 & 0.00 \\
\hline C5ADn/C5ADr & 14.581 & & & & & & & & & $40 \mathrm{H}-1,0$ & 354.40 & 392.08 & 356.44 & 356.44 & 356.44 & 356.44 & 0.00 \\
\hline C5ADr/C5Bn.1 & 14.784 & & & & & $39 \mathrm{H}-2,87^{*}$ & 351.77 & 394.00 & 354.00 & $40 \mathrm{H}-2,72$ & 356.62 & 394.30 & 358. & 358.45 & 358.45 & 358.45 & 0.00 \\
\hline C5Bn.1n/C5Bn.1r & 14.877 & & & & & $39 \mathrm{H}-3,77^{*}$ & 353.17 & 395.40 & 355.26 & $40 \mathrm{H}-3,37$ & 357.77 & 395.45 & 359 & 359.50 & 359.50 & 359.50 & 0.00 \\
\hline C5Bn.1r/C5Bn.2n & 15.032 & & & & & & & & & & 367 & 405.59 & 368 & 368 & 368.72 & 368.72 & 0.00 \\
\hline C5Bn.2n/C5Br & 15.160 & & & & & $40 \mathrm{H}-6,0^{*}$ & 366.40 & 408.80 & 367.30 & $41 \mathrm{H}-5,80$ & 370.70 & 408.99 & 371.81 & 371.81 & 371.81 & 371.81 & 0.00 \\
\hline
\end{tabular}

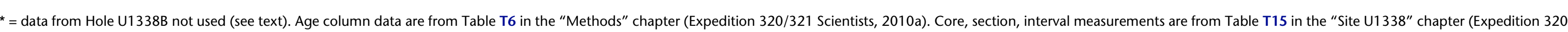
321 Scientists, 2010b). CSF-A and CCSF-A depths are from Table T5 in Wilkens et al. (2013). Revised depth = CCSF-A (m)/hole growth factor (Fig. F1). Bold = shallowest and deepest depths of individual biohorizons. 
Table T4. Age-depth control points (CPs) and linear sedimentation rates (LSRs), Site U1338.

\begin{tabular}{lllccc}
\hline CP & Biohorizons and geomagnetic chron boundaries & $\begin{array}{c}\text { Age } \\
(\mathrm{Ma})\end{array}$ & $\begin{array}{c}\text { Depth } \\
\text { CCSF-B }(\mathrm{m})\end{array}$ & $\begin{array}{c}\text { LSR } \\
(\mathrm{m} / \mathrm{My})\end{array}$ & Figure \\
\hline & Top Site U1338 sediment section & 0.00 & 0.00 & & $\mathrm{F3}$ \\
1 & C1n/C1r (Bruhnes/Matuyama) & 0.781 & 8.98 & 11 & $\mathrm{F3}$ \\
2 & C2n/C2r.1r (Olduvai/Matuyama) & 1.945 & 22.96 & 12 & $\mathrm{F3}$ \\
3 & C2An.3n/C2Ar (Gauss/Gilbert) & 3.596 & 44.24 & 13 & $\mathrm{F3}$ \\
4 & Base Asteromphalus elegans (D) & 4.2 & 53.11 & 15 & $\mathrm{F3}$ \\
5 & Top Ceratolithus acutus (N) & 5.04 & 68.63 & 18 & $\mathrm{F3/F4}$ \\
6 & C4An/C4Ar.1r & 9.098 & 190.60 & 30 & $\mathrm{~F} 4$ \\
7 & C5n.1r/C5n.2n & 9.987 & 205.94 & 17 & $\mathrm{~F} / \mathrm{F} 5$ \\
8 & C5AAn/C5AAr & 13.183 & 315.75 & 34 & $\mathrm{F5}$ \\
9 & C5Bn.2n/C5Br & 15.160 & 371.81 & 28 & $\mathrm{F5}$ \\
10 & Base Discoaster signus (N) & 15.73 & 384.56 & 22 & $\mathrm{F5}$ \\
11 & Base common Sphenolithus heteromorphus (N) & 17.74 & 406.43 & 11 & $\mathrm{F5}$ \\
& Hole U1338B terminal depth & 18.4 & 413.6 & & \\
\hline
\end{tabular}

$\mathrm{D}=$ diatom, $\mathrm{N}=$ nannofossil. 